\title{
REDUCING CRR IN FAST-TRACK PROJECTS THROUGH BIM
}

SUBMITTED: December 2018

REVISED: January 2020

PUBLISHED: February 2020 at https://www.itcon.org/2020/9

EDITOR: Turk Ž.

DOI: $10.36680 /$ j.itcon.2020.009

Marwan Abdelbary

Bartlett School of Construction and Project Management, University College London maroh14@aucegypt.edu

\author{
Andrew Edkins \\ Bartlett School of Construction and Project Management, University College London \\ andrew.edkins@ucl.ac.uk
}

Elkhayam M. Dorra

Construction Engineering Department, School of Sciences and Engineering,

The American University in Cairo

edorra@aucegypt.edu (corresponding author)

\begin{abstract}
Rework is one of the most commonly encountered issues that face construction projects, leading to potential loss of money and delays. The aim of this study is to investigate the potential role of Building Information Modelling (BIM) in reducing Client-Related Rework (CRR) when set within the context of fast-track construction projects in Egypt. In order to study this issue survey data was collected from 51 construction professionals within the Egyptian private construction sector with experience in fast-track projects through a self-administered questionnaire composed of fourteen closed and open-ended subgroup of questions, whose aim is to gain an understanding of the main sources of CRR in the industry. The survey results revealed that the majority of the respondents (92.1\%) had experienced CRR in construction projects, resulting in an average project cost increase of $22 \%$ and an average delay of 23\%, as well as formulating the basis for a novel Severity Index (SI), which was devised in order to rank CRR causes, with its finding revealing "Clients' financial problems", "Impediment in prompting the decision making of the client" and "Replacement of materials by the client", as the biggest contributors to CRR. The survey also highlights visualization as a potential solution to CRR, with eight case studies from literature as well as one from the Egyptian market being used to validate the use of BIM in the reduction of CRR. Findings illustrated that the use of BIM in the Egypt is similar to findings in literature, with BIM resulting in rework cost and schedule reduction of 49 and 57 percent respectively.
\end{abstract}

KEYWORDS: Client-Related Rework, Building Information Modelling, Fast track projects, Egyptian construction

REFERENCE: Marwan Abdelbary, Andrew Edkins, Elkhayam M. Dorra (2020). Reducing CRR in fast-track projects through BIM. Journal of Information Technology in Construction (ITcon), Vol. 25, pg. 140-160, DOI: 10.36680/j.itcon.2020.009

COPYRIGHT: (C) 2020 The author(s). This is an open access article distributed under the terms of the Creative Commons Attribution 4.0 International (https://creativecommons.org/licenses/by/4.0/), which permits unrestricted use, distribution, and reproduction in any medium, provided the original work is properly cited. 
INTRODUCTION

\subsection{Overview}

Egypt is the largest country in the Middle East by population, with over 95 million inhabitants (CAPMAS, 2017). Furthermore, this population is increasing at an annual rate of nearly $1.7 \%$ (World Bank, 2017). Such an ever increasing population reflects an economy that requires significant growth to meet the ever increasing demand. In the beginning of 2014, the Egyptian government has initiated the construction of 20 cities, with a total area of 2.44 square kilometers to house 30 million inhabitants by 2030. Such investments highlight the expected role of the construction industry and the importance of controlling the expenditure on these projects, given the short duration in which these projects are undertaken.

The construction industry is considered to be one of the key pillars of the Egyptian economy. According to the Egyptian Ministry of Planning and Central Bank of Egypt (MOP, 2018; CBE, 2016; CBE, 2017; CBE, 2018) the construction and building sector contributed 9.7, 11.2, 9.5 and 10.3 percent to the total Gross Domestic Product (GDP) in the years 2015, 2016, 2017 and 2018 respectively. Despite its significant role, the construction sector has been facing challenges since the uprisings in 2011. Both the prices and cost of the construction resources such as materials, energy, labor, transport, and other costs have increased significantly, with steel and cement prices rising by nearly 200 percent, between 2013 and 2019 (CAPMAS, 2019). Moreover, in part due to ever increasing inflation which has reached 14 percent on Core Consumer Performance Index (CPI) in January 2018 (CBE, 2018) has significantly increased the Central Bank of Egypt's lending rate which stood at 17.7\% in 2017, making it one of the highest lending interest rates in the world (World Bank, 2017).

The high lending interest rates can lead to significant additional financing costs with the increase in project duration. Accordingly, in a bid to reduce project duration and accordingly financing costs, one such innovative methods that can be used is fast-tracking (Pena-Mora et al. 2001).

Fast-tracking is a construction management strategy to reduce project durations through overlapping project activities that are traditionally sequentially executed. A consequence of the nature of fast-tracked projects is that designs are not always fully complete. It is therefore not surprising to find that fast-tracking has been found to negatively increase project rework (Khoueiry et al. 2012). In mature construction markets such as the United States of America, there is significant expertise and experience in the use of fast-tracking. However, in countries such as Egypt, where fast-tracking is relatively new it is important to investigate the prevalence and causes of rework in fast-tracked construction projects. Such research will be invaluable if there is the anticipated increase in the implementation of such a strategy in the industry, both in Egypt and countries that are in a similar situation.

Rework is a process in which an activity or item is amended to match the project's initial requirements (Hwang et al. 2009). It is considered as a major factor contributing to cost and time overruns (hiring of additional resources, slippage on schedule, or reduction in the scope of the project) in construction projects. Palaneeswaran (2006) stated that in most cases, rework arises from omissions, changes, defects, damage, errors, and other non-conformances with no single party being the sole cause of rework and indeed all project players (clients, consultants, contractors and others) playing a potentially significant role in initiating rework. Love et al. (2010) stated that most construction projects have frequently experienced client-related changes which in-turn generates numerous effects that create disruptions and delays to the project. The final consequences of the rework were highlighted to include the following: higher costs, reduced profits, lower overall productivity, increased turnover of the workforce and management, and finally, the loss of market share and reputation (Love et al. 2010). Although, construction professionals are aware of the fact that rework is a major contributor to poor project performance, incidents of rework still exist in the construction industry. Researchers have exerted many efforts in an attempt to determine the root causes of rework and its negative influence on project performance (Hwang et al. 2009; Palaneeswaran, 2006). However, there are very few studies that have focused on client-related rework (CRR) (Hwang et al. 2014).

\subsection{Fast Tracking in the Construction Industry}

Fast-tracking is a construction management form of procurement to reduce project durations through overlapping design and construction. It was developed for markets such as office buildings where the increased costs necessary to speed delivery was justified in terms of value of the asset created. A consequence of the nature of fast-track projects is that designs are not always fully complete. This method subdivides the project into different work packages to increase the project's flexibility towards changes, enhance overall strategic project control and can 
make it easier when it comes to identifying liabilities (CMAA, 2007). The idea behind this method is to shorten the duration of the project bypassing the traditional sequence of documentation, tendering and construction. It is therefore not surprising to find that fast-tracking has been found to negatively increase project rework (Khoueiry et al., 2012), where rework is defined as "the process by which an item is made to conform to the original requirements by completion or correction" (Hwang et al., 2009). Such rework can lead to loss of time and money in correcting such work, thus affecting project performance.

There are few explanations behind utilizing fast-tracking as procurement method to deliver projects; some of them fall under budgetary, schedule and behavioral aspects. On the financial side, the return on the capital employed is of great significance to all clients within the construction industry. Therefore, clients look to reduce the project's cost. CMAA (2007) stated that by utilizing this strategy, the client could bear with the construction-related risks, implying that the bids of the trade contractors exclude risk premiums. Regarding the time aspect, fast-tracking offers shorter project durations through the ability to overlap both the design and construction activities (Khoueiry et al. 2012). According to Acret (2016), fast-track contracting is popular when interest rates are high. This is primarily attributed to clients wanting to reduce the construction duration of the project due to the high lending interest rates provided by banks and financial institutions, thus raising the financing cost of the project, which is currently evident in the Egyptian construction sector and expected to be prevalent in the upcoming period.

As for the behavioral aspects, Gruneberg and Ive (2000) stated that fast-tracking cancels the zero-sum game situation as it gears down the common construction industry adversarial relationships. In other words, the project is divided into several work packages in addition to, the construction manager (or construction management firm) being paid under a fee system cancels the possibility of opportunism. To summarize, the fast-tracking of the project delivery is driven by business reasons such as the necessity of getting the product to the market in a certain time; the ability to acquire competitive advantage in the market and capacity to leverage the possibility to overlap the design, construction and procurement processes.

In any competitive industry, the reduction of project durations has some notable strategic implications regarding the revenue stream and market share for the clients and contractors. The profits achieved from early completion challenge the clients and project managers to employ fast-tracking techniques in order to achieve shorter project duration. Yet, these strategies might have a negative impact on the performance of any given project by imposing additional risks. That is, increasing the probability of the occurrence of rework in addition to, significantly experiencing both time and cost overruns. It is therefore not surprising to find that fast-tracking has been found to negatively increase project rework (Khoueiry et al. 2012), where rework is defined as "the process by which an item is made to conform to the original requirements by completion or correction" (Hwang et al. 2009). Such rework can lead to loss of time and money in correcting such work, thus affecting project performance.

\section{$1.3 \quad$ Rework}

Rework is considered as a major factor contributing to cost and time overruns (hiring of additional resources, slippage on schedule, or reduction in the scope of the project) in construction projects. Palaneeswaran (2006) stated that in most cases, rework arises from omissions, changes, defects, damage, errors, and other non-conformances with no single party being the sole cause of rework and indeed all project players (clients, consultants, contractors and others) playing a potentially significant role in initiating rework. Love et al. (2010) stated that most construction projects have frequently experienced client-related changes which in-turn generates numerous effects that create disruptions to the project. According to the Construction Industry Institute (CII, 2005), the direct cost of rework is estimated to be $5 \%$ of total construction costs, resulting in approximately 75 billion USD being lost annually to rework in the U.S. alone, while Elvin (2007), estimates this percentage as $12 \%$.

Change orders initiated by the client, also referred to as client-related rework (CRR), have been highlighted as the main cause of rework in construction projects (Hwang et al. 2009; Burati et al. 1992; Palaneeswaran, 2006) defined CRR as changes to the design requested by the clients causing alterations to the construction whether during work being undertaken on-site or after completion. Palaneeswaran (2006) listed various causes of CRR like the lack of adequate funds for site investigations, the absence of client involvement in the stages of the project, insufficient communication with design specialists and absence of key player experience and knowledge.

While a number of definitions regarding CRR exist, few studies have addressed the causes of CRR. Arain and Pheng (2006) identified eight major sources of CRR; change of scope (or plans) by the client, clients' changes to 
schedule, clients' financial problems, replacement of materials/procedures, inadequate project goals, impediment in prompting decision-making processes, clients' stubborn nature, and changes of specifications by the client. While, Ndihokubwayo and Haupt (2008) stated that clients' change orders are due to the clients' changing their minds, lacking a clear project objective or experiencing financial problems. Moreover, the lack of the client's involvement in the early stages can lead to the project team misunderstanding the client's values and requirements (Thomson et al., 2003). This lack of communication between client and design team may also result in omissions and errors in documentation (Love and Edwards, 2004). The lack of information and miscommunication between project entities can thus result in rework at a later stage of the project in order to correct this gap in information.

Whether rework originates from changes and omissions or uncertainty and poor communication, the contributor is still the same. That is to say, project players (clients, contractors, consultants, architects and project managers) are usually the main reason for the occurrence of rework in construction projects. The client being a major project player, is often considered to be the main cause for the occurrence of rework orders due to his very high and increasing expectations (Hwang et al. 2009).

\subsection{Building Information Modeling (BIM)}

Various innovative management conceptions, described by researchers as value enhancing techniques, are being introduced to the construction industry for the pursuit of reduction in project waste through the reduction in rework. With the emergence of Building Information Modelling (BIM), things would become more likely to change. BIM is a unique notion and technology that arose in the market to help overcome traditional 2D design constraints and solve problems concerning changes in designs, which makes it from the most promising and prosperous developments in the Architecture, Engineering, and Construction (AEC) industries. That is to say, it is emerging as the newest possible solution to the rework problem.

According to the US National Building Information Model Standard Committee (NBIMS, 2017), BIM is a "shared knowledge resource for information about a facility forming a reliable basis for decisions during its life-cycle; defined as existing from earliest conception to demolition". Moreover, according to the British Standards Institute (BSI, 2017), "BIM is the management of information through the whole life cycle of a built asset, from initial design all the way through to construction, maintaining and finally de-commissioning, through the use of digital Modelling".

According to a study conducted by Zhang and Wang (2009), the use of BIM can help reduce rework to $0.2 \%$ of the project value, which is significantly lower than the $5 \%$ estimated by CII (2005). This is primarily due to BIM's ability to provide a digital demonstration of the actual physical and functional characteristics of the building before it is actually built, so as to confirm suitability, work out problems as well as simulating and analyzing potential impacts (Smith and Tardif, 2009). Such characteristics ensure that BIM can:

1. Assess different scenarios in addition to, analyzing requirements, budget and owner's feedback (McDuffie, 2006).

2. Enable the clients to obtain reliable and quick cost feedback on modifications during the design stage (Eastman et al., 2011).

3. Provide information easily, thus creating an effective and faster process (CRC, 2007).

4. Visualize design, sequencing and various proposals accurately (CRC, 2007).

All these benefits aid in the client's decision making process, reducing potential CRR, thus assisting in reducing costs, speeding up the construction process (or shortening the construction period), and decreasing the likelihood of legal disputes (Eastman et al. 2011).

Furthermore, as noted by Lee et al. (2012), fast-track projects are expected to have a larger number of changes and thus potential rework. BIM has been shown to reduce potential rework in the Korean construction industry through detecting building-element clashes and other sources of rework. Moreover, in a study conducted by Azhar (2011), even though fast-track project are expected to be highly affected by rework, through the use of BIM in fast-track projects, conflicts were reduced and the client's decision making process was improved thus leading to a reduction in rework. 


\section{OBJECTIVE OF STUDY}

Based on the discussion above, it is evident that fast-tracking is a prevalent strategy that is could potentially dominate the Egyptian construction industry, as well as other developing economies. Such a strategy has inherent risks that could potentially negatively impact the projects' objectives and increase CRR. Furthermore, as previously stated, while extensive research has been conducted on causes of rework, few have focused on CRR as well as means to alleviate the cause. This study investigates the causes of rework in fast-track projects in the Egyptian private construction sector, with particular focus aimed at rework whose main contributor is the client, known as Client-Related Rework (CRR). The aim of such an investigation is to identify the causes that have the greatest impact on both project cost and schedule to help project participants focus their resources on reducing the impact of such causes. Furthermore, the study aims to investigate the use of Building Information Modeling (BIM) in reducing the impact of CRR causes. The aim of such an investigation is to:

1. Identify the causes that have the greatest impact on both project cost and schedule to help project participants focus their resources on reducing the impact of such causes.

2. Investigate the use of Building Information Modeling (BIM) in reducing the impact of CRR causes.

\section{METHODOLOGY}

\subsection{Research Methodology}

The conducted literature review formed the basis for developing a self-administered questionnaire survey that will be used to identify the main causes of CRR, as well as to examine the use of BIM's in reducing CRR in fast-track projects in the Egyptian private sector. The design of the questionnaire and potential causes of CRR has been extracted from previous studies (Palaneeswaran, 2006; Hwang et al. 2014; Arian and Pheng, 2006; Ndihokubwayo and Haupt, 2008; Thomson et al. 2003; Love and Edwards, 2004). Nonetheless, the questionnaire in this study aims to not only identify the causes of CRR but also towards assessing the impact of each of the causes of CRR on project performance criteria, primarily time, cost and quality, as well as exploring the emergence of BIM as a possible solution to CRR.

This research is considered to be explanatory as it intends to identify the causes of CRR in fast-track construction projects, the impact of CRR on project performance in terms cost and schedule performance, and the solutions previously implemented to prevent the occurrence of CRR. Additionally, the research aims at determining the current awareness of the Egyptian private sector construction market with regards to building information modeling (BIM). Whereas, it is descriptive as it is used for obtaining the insights, perceptions, and views of the interviewees regarding the potential benefits of BIM in reducing client-related rework in addition to, the challenges BIM would face to be utilized in the Egyptian construction market.

\subsection{Questionnaire Design}

The questionnaire was used to achieve anonymity as well as the need for bias avoidance (Marshall, 2005). Although this is a quantitative method, it was essential to have a mix of both closed and open-ended questions, with the purpose of obtaining deeper opinions and thoughts from the sample. A mixture of rating (Likert scale), ranking, and multiple-choice questions, were used as a part of the closed questions.

The questionnaire consisted of three sections. The first section included questions to profile the respondents. In the second section, the respondents were asked to rank six project players according to their contribution to rework, provide the number of the projects that they were involved in during the past five years and the number of the projects with CRR, and assess the percentage of cost increase and the length of schedule delay caused by CRR on each of these projects. Additionally, respondents were also asked to rate the frequency of occurrence and the contribution of the six causes of CRR, which had been identified by the literature as being the main causes of CRR and to specify the methods implemented to reduce the CRR as well as their effectiveness. Finally, the third section consisted of open-ended questions for the respondents to provide their opinions regarding the potential benefits that BIM techniques would offer in enhancing the reduction of the client-related rework as well as the limitations for its application in the Egyptian market.

A pilot of the survey was initially developed and tested on three practitioners having over 10 years of experience in the Egyptian construction sector to validate the questionnaire and to help identify potential causes of delay. 
Based on feedback received from the experts, as well similar studies (Palaneeswaran, 2006; Hwang et al. 2014; Arian and Pheng, 2006; Ndihokubwayo and Haupt, 2008; Thomson et al. 2003; Love and Edwards, 2004) (Table 1 ), seven main causes of CRR were identified as presented in

Table 2 .

TABLE 1. Causes of CRR throughout literature (Palaneeswaran, 2006; Hwang et al. 2014; Arian and Pheng, 2006; Ndihokubwayo and Haupt, 2008; Thomson et al. 2003; Love and Edwards, 2004).

\begin{tabular}{|c|c|c|c|c|c|c|}
\hline \multirow{2}{*}{ Causes of CRR } & \multicolumn{6}{|c|}{ References } \\
\hline & 1 & 2 & 3 & 4 & 5 & 6 \\
\hline $\begin{array}{l}\text { Impediment in prompting decision } \\
\text { making processes }\end{array}$ & $\sqrt{ }$ & & & $\sqrt{ }$ & & $\sqrt{ }$ \\
\hline $\begin{array}{c}\text { Replacement of materials by the } \\
\text { client }\end{array}$ & $\sqrt{ }$ & & & & & $\sqrt{ }$ \\
\hline Clients' financial problems & $\sqrt{ }$ & & $\sqrt{ }$ & & & $\sqrt{ }$ \\
\hline Change of Scope by the client & & & $\sqrt{ }$ & & & $\sqrt{ }$ \\
\hline $\begin{array}{l}\text { Poor communication with design } \\
\text { team }\end{array}$ & & $\sqrt{ }$ & & & $\sqrt{ }$ & $\sqrt{ }$ \\
\hline $\begin{array}{l}\text { Clients' lacking a clear project } \\
\text { objective }\end{array}$ & $\sqrt{ }$ & & $\sqrt{ }$ & & & $\sqrt{ }$ \\
\hline $\begin{array}{c}\text { Clients' Lack of experience and } \\
\text { knowledge }\end{array}$ & & $\sqrt{ }$ & & & & $\sqrt{ }$ \\
\hline
\end{tabular}

TABLE 2: Identified primary causes of CRR

\begin{tabular}{|c|c|}
\hline Causes of CRR & Examples \\
\hline $\begin{array}{l}\text { Impediment in prompting } \\
\text { decision making processes }\end{array}$ & $\begin{array}{l}\text { The inefficient decision making process of the client. An example of this would be the Client's } \\
\text { reluctance to make decisions regarding hiring a specialty contractor. If the client delays hiring an } \\
\text { Electro-Mechanical contractor, then rework of masonry work might take place due to the delay in } \\
\text { executing required MEP provisions. }\end{array}$ \\
\hline $\begin{array}{l}\text { Replacement of materials by } \\
\text { the client }\end{array}$ & $\begin{array}{l}\text { As materials have different prices and adopt different standards, the change of materials used in projects } \\
\text { would impact project cost, quality and time. An example of this cause has been experienced by an } \\
\text { interviewed expert where a client replaced ceramic flooring with High-Density Fiberboard (HDF) after a } \\
\text { percentage of the ceramic floor had been executed. This resulted in delay of time and additional cost. }\end{array}$ \\
\hline Clients' financial problems & $\begin{array}{l}\text { Financial difficulties faced by the client would impact its ability to fund the project. Thus, the client } \\
\text { would be forced to reduce the project budget and issue change orders. }\end{array}$ \\
\hline $\begin{array}{l}\text { Change of Scope by the } \\
\text { client }\end{array}$ & $\begin{array}{l}\text { The change of project plans or scope initiated by the client after the work is undertaken means re-doing } \\
\text { the work according to the new plans or scope. }\end{array}$ \\
\hline $\begin{array}{l}\text { Poor communication with } \\
\text { design team }\end{array}$ & $\begin{array}{l}\text { Deficiencies in communication flow between the client and design team members can result in } \\
\text { documentation errors and omissions occurring (Dalty and Crawshaw, 1973). }\end{array}$ \\
\hline $\begin{array}{l}\text { Clients' lacking a clear } \\
\text { project objective }\end{array}$ & $\begin{array}{l}\text { The inadequate project objectives identified by the client made it possible to re-define these objectives } \\
\text { subject to the expectations of the client, and the re-defined ones would be different from the ones that } \\
\text { were understood by the contractors, which led to CRR in the construction phase of projects }\end{array}$ \\
\hline $\begin{array}{l}\text { Clients' Lack of experience } \\
\text { and knowledge }\end{array}$ & $\begin{array}{l}\text { The inefficient decision making process of the client, which may be due to their inexperience and } \\
\text { hesitation, would result in the client altering decisions during the lifetime of the project. Such an example } \\
\text { was highlighted by an interviewed expert who altered the HVAC system in a project three times, while } \\
\text { execution was taking place, resulting in loss of time and money. }\end{array}$ \\
\hline
\end{tabular}


Following an exercise to identify those with expected relevant knowledge and experience, a total of one hundred and twenty (120) questionnaires were sent and out with fifty-one (51) responses returned, representing a response rate of $42.5 \%$. Such a response rate is considered both successful in terms of uptake and such a sample size is in line with finding of both Dornyei (2003) as well as Roscoe (1975).

The data was obtained from professionals working in the Egyptian private construction sector. The respondents were drawn from populations comprising experienced clients, contractors, consultants, architects and project managers, with experience in fast-track projects that are registered as professional engineers in the Egyptian Syndicate of Engineers.

Based on the results obtained from the survey, case studies from the market and from literature will be used to validate the findings of the survey in order to identify the potential application of BIM in the reduction of CRR.

\section{$4 \quad$ RESULTS AND ANALYSIS}

\subsection{Respondents' Profile}

FIG. 1 and FIG. 2 presents a breakdown of the study participants by role and years of experience.

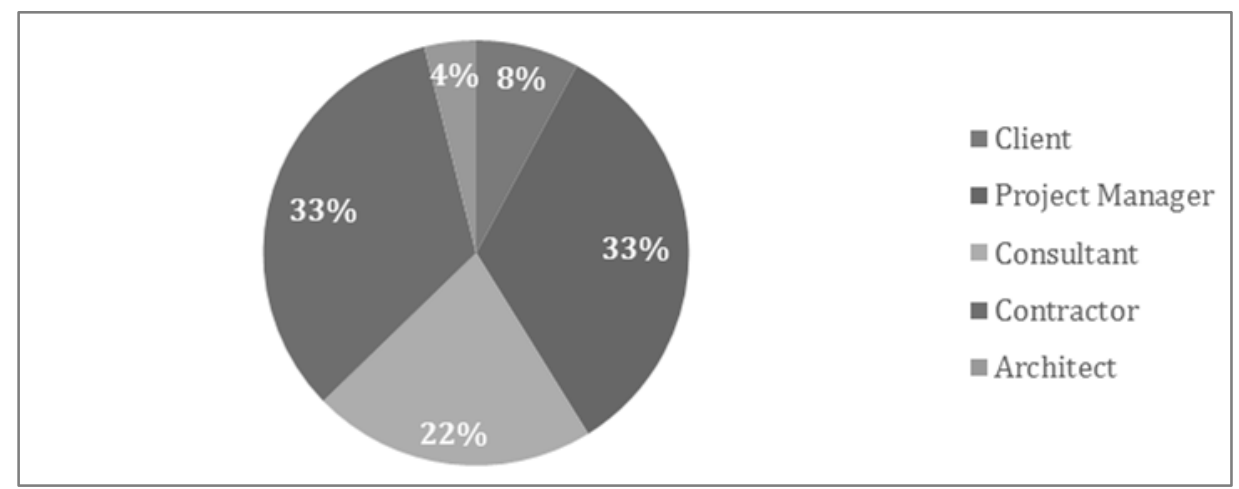

FIG. 1: Study participants by role

As shown in FIG. 1, the majority of the respondents were from clients and clients' representatives (CRs), i.e. consultants, architects and project managers, representing 67 percent of the sample. The remaining 33 percent were contractors. Moreover, 51 percent of respondents had over 10 years of experience, highlighting their strong understanding of the Egyptian construction industry.

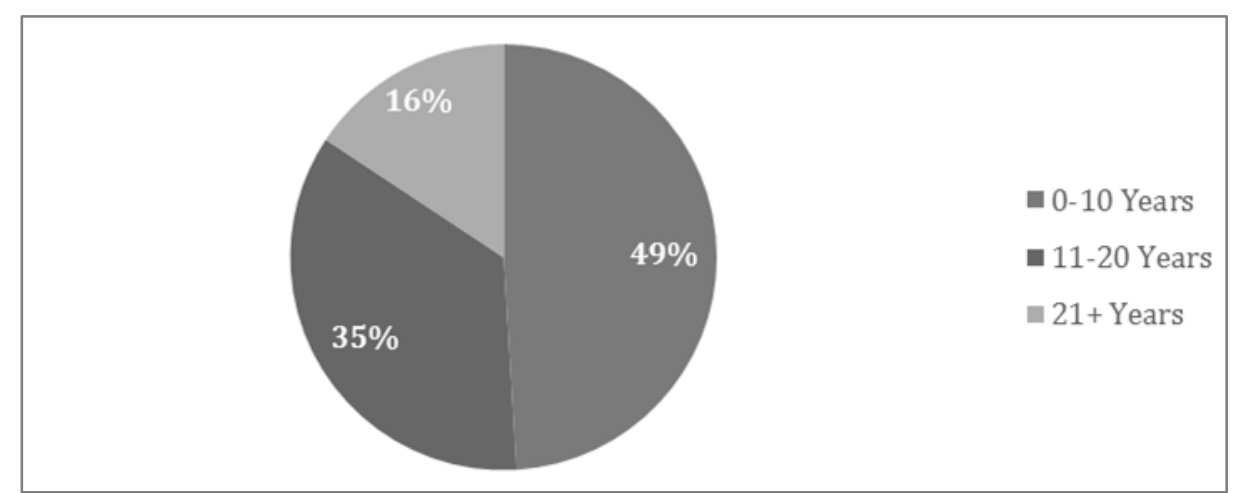

FIG. 2: Study participants by years of experience

\subsection{Client-Related Rework (CRR)}

\subsubsection{Contribution of Project Players to Rework Occurrence}

Six project players were identified by this study as possible contributors to the occurrence of rework in fast-track 
construction projects. The respondents were requested to rank their contribution to rework using a rating scale from 1 to 6 ( 1 = Highest Contribution, and $6=$ Least Contribution) (TABLE. 3$)$.

TABLE. 3: Overall, Client Representatives and Contractor rankings of contributor to rework by project participants

\begin{tabular}{|c|c|c|c|c|c|c|}
\hline \multirow{2}{*}{ Project Players } & \multicolumn{2}{|c|}{ Overall $(\mathrm{N}=51)$} & \multicolumn{2}{|c|}{ Clients (including CRs) $(\mathrm{N}=34)$} & \multicolumn{2}{|c|}{ Contractors $(\mathrm{N}=17)$} \\
\hline & Mean & Rank & Mean & Rank & Mean & Rank \\
\hline Client & 4.84 & 1 & 4.74 & 1 & 5.06 & 1 \\
\hline Architect & 4.22 & 2 & 4.09 & 2 & 4.47 & 2 \\
\hline Contractor & 3.78 & 3 & 4.08 & 3 & 2.88 & 5 \\
\hline Project Manager & 3.51 & 4 & 3.50 & 4 & 3.53 & 3 \\
\hline QS & 2.43 & 5 & 2.21 & 6 & 3.00 & 4 \\
\hline Supplier & 2.22 & 6 & 2.38 & 5 & 2.06 & 6 \\
\hline
\end{tabular}

The "Client" and "Architect" were respectively ranked as first and second contributing parties to rework occurrence, obtaining mean scores of 4.48 and 4.22 respectively by the 51 respondents. Furthermore, to ensure that the results are not influenced by the role of respondents, the results of the Client Representatives' (CRs) (client, project manager, consultant and architect) data was compared to those received from contractors. While the crossrole analysis yielded an overall change in ranking, with client representatives ranking the role of contractors as the third largest contributor to CRR, while contractors viewing their role as fifth largest contributor in both cases the Client and Architect were both found to be the biggest contributors to CRR.

\subsubsection{Existence of CRR on Fast Track Projects}

The respondents were asked to provide the number of fast-track projects that they were involved in during the past three years and how many of these projects experienced CRR. Based on such findings the Client-Related Rework Index (CRRI) (Equation (1)) was calculated to gauge the existence of CRR in the experienced of the study participants (Hwang et al., 2014).

$$
\operatorname{CRRI}(\%)=\left(\frac{N}{T}\right) \times 100 \quad \text { Equation (1) }
$$

where $N$ and $T$ are the number of fast track projects the participant has been involved in over the past three years and the number of projects that experienced CRR respectively.

FIG. 3 presents the CRRI for the sampled population. As shown 92 percent of the experts surveyed have experienced CRR in at least one of the projects they have been involved in. This indicates that CRR is a common problem in Egyptian private sector fast-track construction projects and needs to be addressed.

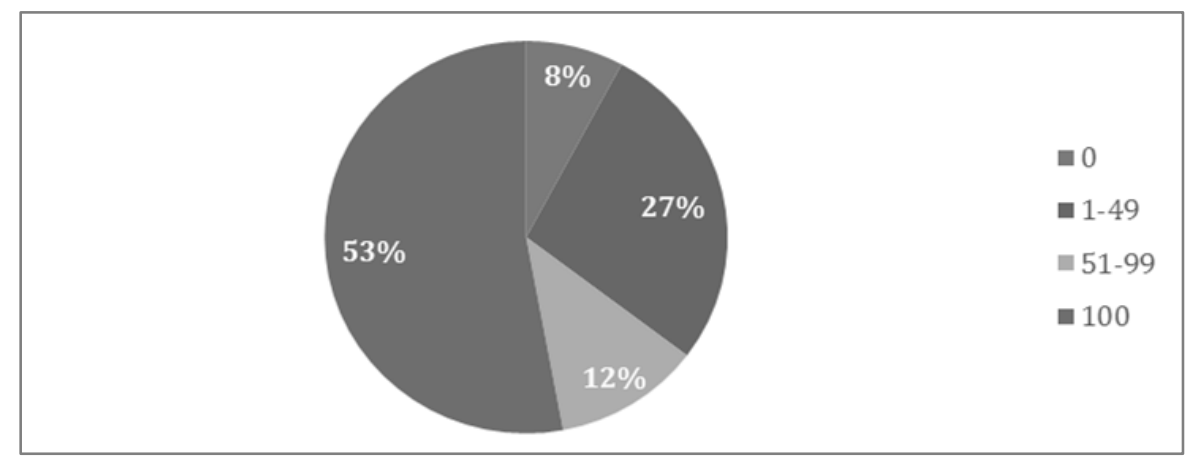

FIG. 3: Client-Related Rework Index (CRRI) for the sampled population 


\subsubsection{Causes of CRR in Egyptian Fast-Track Projects}

Seven factors, which caused clients to initiate rework in construction projects, were identified through the literature review and presented to the respondents. The professionals were requested to rate the frequency of occurrence of these causes, their contribution to CRR as well as their impact on project performance using the five-point Likert scales $(1=$ Very Low, and $5=$ Very High $)$.

TABLE 4 presents the results obtained from expert ranking of CRR causes by frequency of occurrence of such causes, presented through results obtained from the 51 experts surveyed, as well as analyzed between the CRs and Contractors. The mean overall frequency of occurrence ranking for each of the causes exceeds 3.00 clearly illustrating that each of the causes listed have been experienced by experts sampled.

Moreover, when analyzing results obtained from the 51 experts, the highest three ranked causes in terms of frequency of occurrence are "clients' financial problems", "impediment in promoting decision making processes" and replacement of materials by client" all received a mean ranking of 3.76 .

Furthermore, a one sample t-test was conducted against a test value of 3.00 as noted in TABLE 4. Two of the causes of CRR had a $p$ value $<0.05$ illustrating the likelihood that they would occur. These causes are, "impediment in prompting decision making processes" and "replacement of material by the client". Furthermore, to further check the correlation in results between CRs and Contractors a one variable ANOVA analysis was conducted. As noted in TABLE 4 all of the causes presented $p$ values $>0.05$ when comparing between the two groups, with the exception of "clients' lack of experience and knowledge" and "replacement of materials by the client". Thus there were significant differences between the two analyzed groups for the two causes highlighted, while for the remaining five causes the difference were not significant.

TABLE 4: Overall, Client Representatives and Contractor rankings of CRR causes frequency ranking

\begin{tabular}{|c|c|c|c|c|c|c|c|c|}
\hline \multirow{2}{*}{ Causes of CRR } & \multicolumn{3}{|c|}{ Overall $(\mathrm{N}=51)$} & \multicolumn{2}{|c|}{$\begin{array}{l}\text { Clients (including } \\
\text { CRs) }(\mathrm{N}=34)\end{array}$} & \multicolumn{2}{|c|}{$\begin{array}{l}\text { Contractors and other } \\
\text { professions }(\mathrm{N}=17)\end{array}$} & \multirow[b]{2}{*}{$p$ value } \\
\hline & Mean & Rank & $p$ value & Mean & Rank & Mean & Rank & \\
\hline $\begin{array}{l}\text { Impediment in prompting } \\
\text { decision making processes }\end{array}$ & 3.76 & 1 & 0.029 & 3.79 & 2 & 3.71 & 2 & 0.448 \\
\hline $\begin{array}{l}\text { Replacement of materials by the } \\
\text { client }\end{array}$ & 3.76 & 1 & 0.019 & 3.71 & 3 & 3.88 & 1 & 0.010 \\
\hline Clients' financial problems & 3.76 & 1 & 0.213 & 3.94 & 1 & 3.41 & 3 & 0.789 \\
\hline Change of Scope by the client & 3.53 & 4 & 0.642 & 3.62 & 4 & 3.35 & 4 & 0.773 \\
\hline $\begin{array}{c}\text { Poor communication with } \\
\text { design team }\end{array}$ & 3.41 & 5 & 0.780 & 3.44 & 5 & 3.35 & 4 & 0.863 \\
\hline $\begin{array}{c}\text { Clients' lacking a clear project } \\
\text { objective }\end{array}$ & 3.33 & 6 & 0.662 & 3.32 & 6 & 3.35 & 4 & 0.786 \\
\hline $\begin{array}{c}\text { Clients' Lack of experience and } \\
\text { knowledge }\end{array}$ & 3.25 & 7 & 0.995 & 3.32 & 6 & 3.12 & 7 & 0.015 \\
\hline
\end{tabular}

\subsubsection{Contribution of the causes of CRR}

Furthermore, each of the experts were asked to indicate which of the causes listed had the largest impact on CRR. The mean scores for the impact of all the seven causes were calculated, and the results are presented hereafter in TABLE 5.

Analyzing results obtained from the 51 experts it can be seen that "replacement of materials by the client" was ranked as the cause with the largest impact on CRR with a mean score of 4.24. In the event that the client replaces a project material, then work has to be redone with the new specified material, resulting in significant impact.

Moreover, the results were also examined by analyzing the results of CRs and Contractors separately. It is evident 
that the results deviate significantly when comparing results obtained from CRs versus those from Contractors. While CRs ranked "replacement of materials by the client" as significantly the highest contributor to CRR with a mean score of 4.68, Contractors ranked this cause sixth. Such findings clearly illustrate the opposing perspective each party has towards CRR. This is reflective of the poor communication in that is endemic throughout the Egyptian construction industry (Swefie 2013; Marzouk and El Rasas 2014), that results in a lack of consensus and vision in tackling the causes of CRR.

TABLE 5: Overall, Client Representatives and Contractor rankings of CRR causes contribution ranking

\begin{tabular}{|c|c|c|c|c|c|c|c|c|}
\hline \multirow{2}{*}{ Causes of CRR } & \multicolumn{3}{|c|}{ Overall $(\mathrm{N}=51)$} & \multicolumn{2}{|c|}{$\begin{array}{l}\text { Clients (including } \\
\text { CRs) }(\mathrm{N}=34)\end{array}$} & \multicolumn{2}{|c|}{$\begin{array}{l}\text { Contractors and other } \\
\text { professions }(\mathrm{N}=17)\end{array}$} & \multirow[b]{2}{*}{$\mathrm{p}$ value } \\
\hline & Mean & Rank & $\mathrm{p}$ value & Mean & Rank & Mean & Rank & \\
\hline $\begin{array}{l}\text { Replacement of materials by the } \\
\text { client }\end{array}$ & 4.24 & 1 & 0.001 & 4.68 & 1 & 3.35 & 6 & 0.150 \\
\hline Change of Scope by the client & 4.10 & 2 & 0.089 & 4.06 & 2 & 4.18 & 2 & 0.545 \\
\hline $\begin{array}{c}\text { Clients' lacking a clear project } \\
\text { objective }\end{array}$ & 3.67 & 3 & 0.443 & 3.50 & 5 & 4.00 & 3 & 0.748 \\
\hline $\begin{array}{l}\text { Impediment in prompting } \\
\text { decision making processes }\end{array}$ & 3.63 & 4 & 0.066 & 3.15 & 6 & 4.59 & 1 & 0.588 \\
\hline Clients' financial problems & 3.61 & 5 & 0.576 & 3.68 & 3 & 3.47 & 4 & 0.456 \\
\hline $\begin{array}{l}\text { Poor communication with } \\
\text { design team }\end{array}$ & 3.57 & 6 & 0.619 & 3.65 & 4 & 3.41 & 5 & 0.401 \\
\hline $\begin{array}{l}\text { Clients' Lack of experience and } \\
\text { knowledge }\end{array}$ & 3.10 & 7 & 0.780 & 3.09 & 7 & 3.12 & 7 & 0.314 \\
\hline
\end{tabular}

Moreover, a one-sample t-test was also conducted to compare the contribution of each of the causes of CRR. As can be seen in TABLE 5 the "impediment in prompting decision making processes" and replacement of materials by the client" both presented a $\mathrm{p}$ value $<0$, indicating that these two significantly contributed to CRR. Moreover, when comparing the results between the two samples groups (CRs and Contractors) using ANOVA analysis, all of the causes presented $p$ values $>0$ meaning that there is no significant difference between in the results between both groups.

Moreover, when analyzing the results presented by the one-sample t-test it is evident that "replacement of materials by the client" and "change of scope by the client" had a $p$ value $<0$ for its impact on cost, meaning that it was likely to contribute to such an impact. Furthermore, "clients' financial problems" presented a $p$ value $<0$ for its impact on quality highlighting the importance of addressing this cause due to its significance on influencing quality of construction works and reduction of rework.

Furthermore, intergroup comparison was conducted in order to assess the feedback received from CRs and Contractors on the impact of CRR causes on project cost, schedule and quality (TABLE 6) (FIG. 4-FIG. 6). It is clear that CRs and Contractors mostly agreed on the overall ranking of the impact of CRR on cost with "change of scope" being viewed as the first and second ranked cause by the CRs and Contractors respectively. Furthermore, both parties viewed the "client's lack of experience and knowledge" as the least ranked cause of CRR.

Both CRs and Contractors continued to view "change of scope" as having significant impact on project schedule with CRs and Contractors ranking the cause in second and first place respectively. Nonetheless, while Contractors viewed "replacement of materials" as having the greatest impact on project cost, they ranked this cause as having the fourth largest impact on project schedule. This differs significantly from the feedback received from CRs that viewed this cause as having the greatest impact on project schedule. 
TABLE 6: Impact of CRR on project cost, schedule and quality

\begin{tabular}{|c|c|c|c|c|c|c|c|c|c|}
\hline \multirow[t]{2}{*}{ Causes of CRR } & \multicolumn{3}{|c|}{ Cost } & \multicolumn{3}{|c|}{ Schedule } & \multicolumn{3}{|c|}{ Quality } \\
\hline & Mean & Rank & $\mathrm{p}$ value & Mean & Rank & $\mathrm{p}$ value & Mean & Rank & $\mathrm{p}$ value \\
\hline $\begin{array}{c}\text { Replacement of materials } \\
\text { by the client }\end{array}$ & 4.22 & 1 & 0.001 & 4.35 & 1 & 0.653 & 3.71 & 2 & 0.921 \\
\hline $\begin{array}{c}\text { Change of Scope by the } \\
\text { client }\end{array}$ & 4.15 & 2 & 0.048 & 4.14 & 2 & 0.286 & 3.29 & 6 & 0.409 \\
\hline Clients' financial problems & 3.76 & 3 & 0.299 & 3.71 & 4 & 0.506 & 4.24 & 1 & 0.011 \\
\hline $\begin{array}{l}\text { Impediment in prompting } \\
\text { decision making processes }\end{array}$ & 3.73 & 4 & 0.279 & 3.69 & 5 & 0.283 & 3.27 & 5 & 0.874 \\
\hline $\begin{array}{c}\text { Poor communication with } \\
\text { design team }\end{array}$ & 3.69 & 5 & 0.399 & 3.37 & 6 & 0.525 & 3.69 & 3 & 0.357 \\
\hline $\begin{array}{c}\text { Clients' lacking a clear } \\
\text { project objective }\end{array}$ & 3.55 & 6 & 0.662 & 3.84 & 3 & 0.066 & 3.63 & 4 & 0.386 \\
\hline $\begin{array}{c}\text { Clients' Lack of experience } \\
\text { and knowledge }\end{array}$ & 3.04 & 7 & 0.111 & 3.02 & 7 & 0.228 & 3.00 & 7 & 0.643 \\
\hline
\end{tabular}

Change of Scope by the client

Replacement of materials by the client Clients' Lack of experience and knowledge

Poor communication with design team Impediment in prompting decision making processes

Clients' financial problems

Clients' lacking a clear project objective

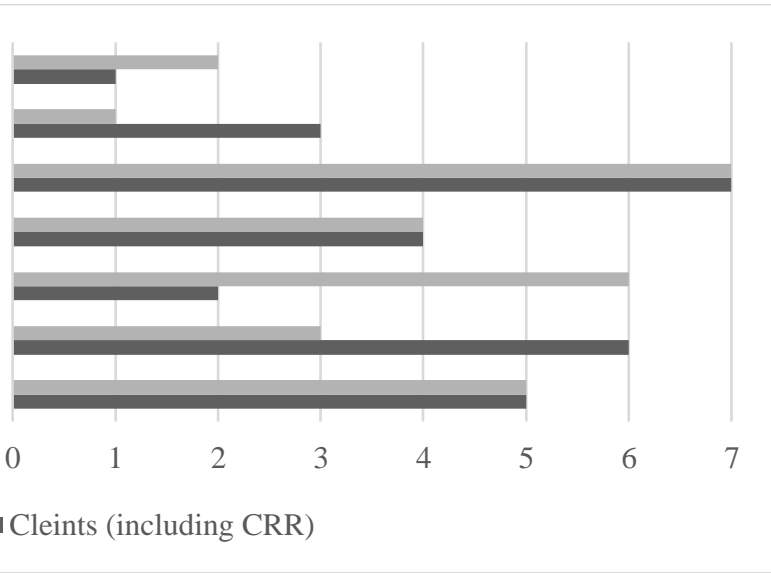

- Contractors $\square$ Cleints (including CRR)

FIG. 4: Client Representatives and Contractor impact ranking of CRR causes on cost of Egyptian fast track projects

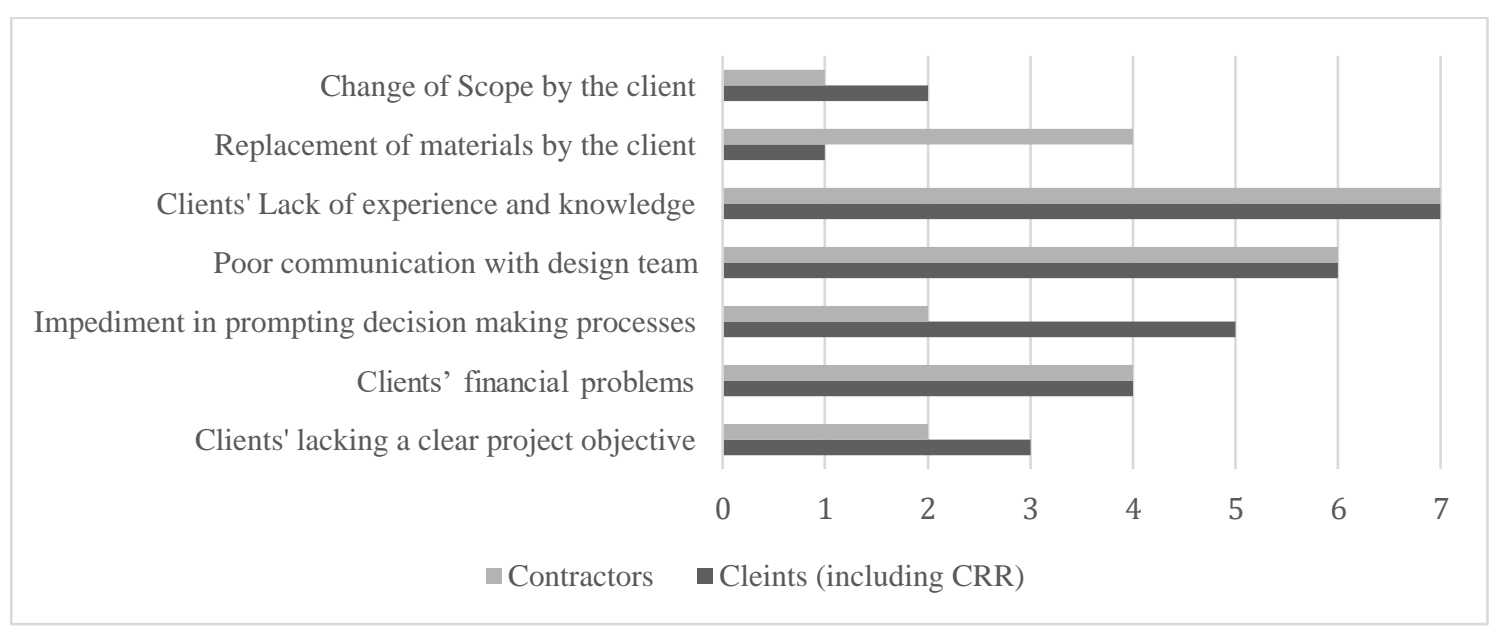

FIG. 5: Client Representatives and Contractor impact ranking of CRR causes on schedule of Egyptian fast track projects 


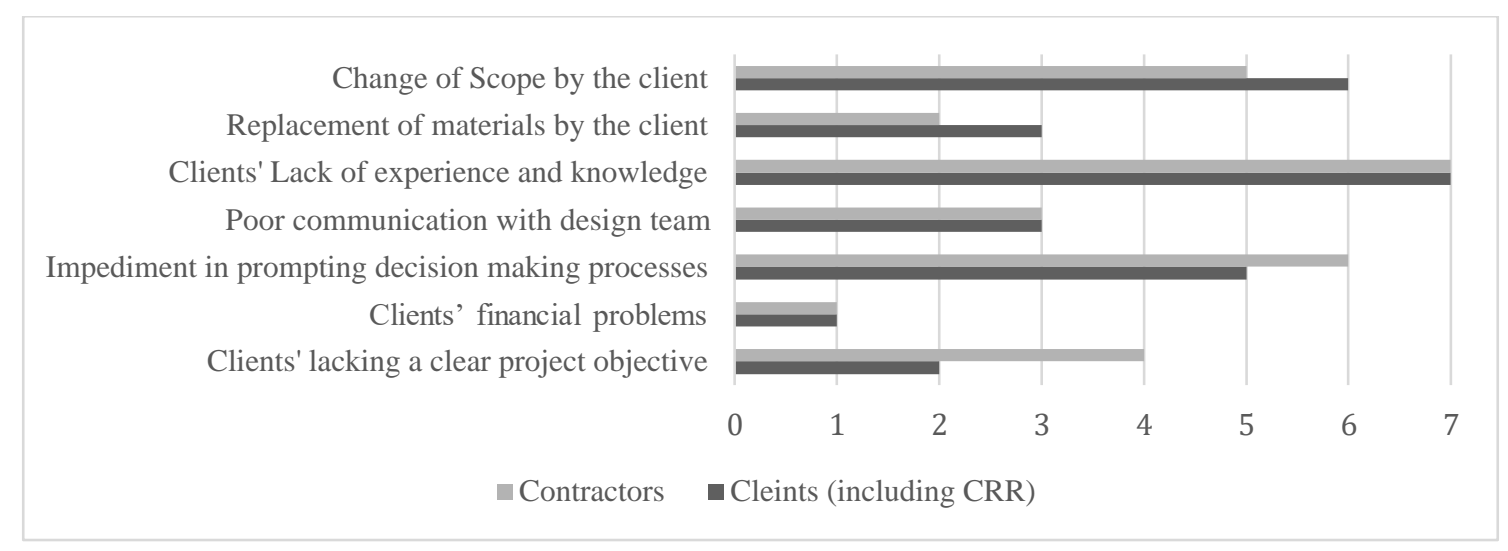

FIG. 6: Client Representatives and Contractor impact ranking of CRR causes on cost of Egyptian fast track projects

\subsubsection{Cost and Schedule Delay Overruns by CRR}

The respondents were also asked to assess the percentage of cost increase and the length of schedule delay that were caused by CRR. The respondents stated that CRR increased project cost by an average of 22 percent of the original project value, further leading to project delays of 35.2 weeks on projects that have an average planned duration of 156 weeks, thus presenting a 23 percent delay in project duration.

\subsubsection{Weighted Severity Index}

In order to accurately evaluate causes of CRR and highlight which of these causes project participants should focus resources towards, a novel approach was proposed in this study. Neither frequency of occurrence nor impact of the cause of present the severity of such a cause. While frequency gauges whether a cause "may" occur, it does not highlight the impact of such a cause in the event it does occur. Thus, even if a cause has a high probability of taking place, if the impact of this cause on CRR is low than it might not be of great importance. Moreover, in the event that a cause has a high impact when it does take place but is unlikely to occur, then this cause might also be deprioritized when evaluating causes of CRR. Accordingly, in order to address this issue the "Weighted Severity Index" (WSI) of each cause of CRR was calculated. WSI is a measure that accounts for both Frequency (F) and Impact (I) to ensure that the cause is ranked in a manner that reflects both the probability and the impact of the cause raking place.

Since Impact $(I)$ has been calculated on cost, schedule and quality, it is important to calculate an overall impact metric that accounts for all three estimates. Equation (2) presents an estimate of Impact (I) based on taking a weighted average of the Impact on Cost $\left(I_{c}\right)$, Impact on Schedule $\left(I_{s}\right)$ and Impact on Quality $\left(I_{q}\right)$. Depending on the importance of each of these performance criteria, the weights of each of these criteria can be altered using $W_{c}, W_{s}$ and $W_{q}$ for cost, schedule and quality respectively. In this study each of the criteria were given equal weights.

$$
I=W_{\mathrm{c}} \times I_{\mathrm{c}}+W_{s} \times I_{s}+W_{q} \times I_{q}
$$

Equation (2)

where:

$$
W_{\mathrm{c}}+W_{s}+W_{q}=1
$$

Furthermore, based on the estimated Impact $(I)$ and Frequency $(F)$ of each causes of CRR, the Weighted Severity Index (WSI) can be calculated as shown in Equation (4).

$$
W S I=\frac{F^{W_{F}} \times I^{W_{I}}}{5}
$$

As noted in Equation (4) the severity is scaled by a coefficient of 5. Since both Frequency and Impact are measured from $1-5$, thus by scaling severity as such it leads to a variable that ranges in value from $0-1$. Similarly, WSI is weighted between Frequency $(F)$ and Impact $(I)$ through the use of $W_{F}$ and $W_{I}$ respectively. If a project participant is fearful of high impact CRR causes irrespective of their frequency, then the Weight of Impact $W_{I}$ is increased against that of frequency $W_{F}$. In this study the weights were taken as equal. 
TABLE 7 presents the WSI ranking for the overall sample, clients and contractors. Overall, "replacement of materials by client" and "client's financial problems" ranked as the most severe causes. Moreover, four causes had a $p$ value $<0.05$, these being "replacement of materials by client", "client's financial problems", "impediment in prompting decision making process" and "change of scope by the client". It is necessary to tackle and monitor the source of such causes carefully due to their severe nature. Moreover, when comparing the results obtained between the two different groups, all the causes with the exception of "replacement of materials by the client" scored a $p$ value $>0$. Thus there is significant difference between in the results between both groups, when it comes to such a cause.

TABLE 7: Overall, Client Representatives and Contractor ranking of CRR causes severity (WSI) ranking

\begin{tabular}{|c|c|c|c|c|c|c|c|c|}
\hline \multirow[t]{2}{*}{ Causes of CRR } & \multicolumn{3}{|c|}{ Overall $(\mathrm{N}=51)$} & \multicolumn{2}{|c|}{$\begin{array}{l}\text { Clients (including } \\
\text { CRs) }(\mathrm{N}=34)\end{array}$} & \multicolumn{2}{|c|}{$\begin{array}{l}\text { Contractors and } \\
\text { other professions } \\
(\mathrm{N}=17)\end{array}$} & \multirow[b]{2}{*}{$\mathrm{p}$ value } \\
\hline & Mean & Rank & $\mathrm{p}$ value & Mean & Rank & Mean & Rank & \\
\hline $\begin{array}{l}\text { Replacement of materials by the } \\
\text { client }\end{array}$ & 0.80 & 1 & 0.001 & 0.74 & 2 & 0.92 & 1 & 0.005 \\
\hline Clients' financial problems & 0.72 & 2 & 0.002 & 0.67 & 1 & 0.81 & 3 & 0.238 \\
\hline $\begin{array}{c}\text { Impediment in prompting decision } \\
\text { making processes }\end{array}$ & 0.71 & 3 & 0.006 & 0.73 & 3 & 0.66 & 2 & 0.622 \\
\hline Change of Scope by the client & 0.68 & 4 & 0.043 & 0.72 & 1 & 0.59 & 5 & 0.430 \\
\hline $\begin{array}{c}\text { Clients' lacking a clear project } \\
\text { objective }\end{array}$ & 0.62 & 5 & 0.099 & 0.61 & 5 & 0.65 & 4 & 0.801 \\
\hline $\begin{array}{l}\text { Poor communication with design } \\
\text { team }\end{array}$ & 0.62 & 6 & 0.080 & 0.65 & 4 & 0.55 & 6 & 0.511 \\
\hline $\begin{array}{l}\text { Clients' Lack of experience and } \\
\text { knowledge }\end{array}$ & 0.50 & 7 & 0.423 & 0.49 & 6 & 0.53 & 7 & 0.797 \\
\hline
\end{tabular}

Moreover, in order to measure the effect of weights in the WSI calculation, a sensitivity analysis was conducted. A Monte-Carlo simulation was conducted in which the weights in Equations (2)-(4) were randomly selected 1000 times, with the combination of each of these weights being used in order to calculate the WSI. Furthermore, once WSI was estimated based for each of the 1000 runs the ranking of each cause was found. FIG. 7 presents the findings from this analysis highlight the frequency that each of the causes of CRR were ranked for each of the 1000 runs. As noted "Replacement of materials by the client" was ranked as the most severe cause of CRR 99.8\% of the time. Moreover, "Impediment in prompting decision making process" was ranking as the second most severe cause of CRR $52.6 \%$ of the time. Such findings highlight that while each of the weights can affect severity calculations, the top two causes of CRR identified according to WSI are not sensitive to such changes, thus highlighting the need to focus resources to both of these causes irrespective of weights being employed in the calculations.

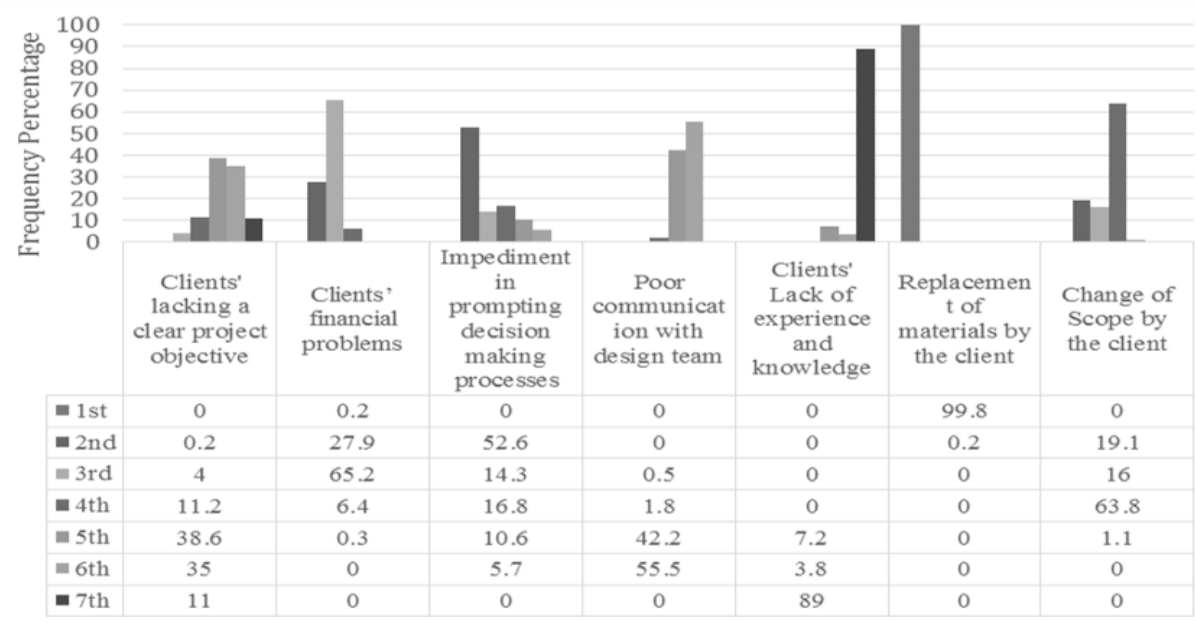

FIG. 7: Frequency of WSI ranking by causes of CRR 


\subsection{Building Information Modeling (BIM) as a solution to CRR}

Four questions, using a mix of both closed and open-ended questions (two questions each), were designed to determine the current awareness of the Egyptian construction market with regards to BIM. The closed questions aimed at identifying the respondent's familiarity with the BIM software as well as the current status of the use of BIM in fast-track projects. These questions were in the form of multiple choice questions, where the respondents were only allowed to choose one of the given choices. Whereas, the open-ended questions focused on respondent's opinions regarding the possible benefits that BIM would offer if it is implemented in fast-track projects and the challenges (or limitations) it would face for its application in the Egyptian construction market.

\subsubsection{BIM in the Egyptian Market}

Over 88 percent of respondents stated their familiarity with BIM and Computer Visualization Techniques. Nonetheless, nearly 71 percent of those samples stated that BIM are never used in the Egyptian construction market, with nearly 27 percent stating that they are sometimes used (FIG. 8). Only one of the 51 respondents highlighted their consistent use of BIM in the Egyptian construction industry. Such finding highlights the lack of use of BIM in the market, and thus the inability to realize the potentials offered by BIM.

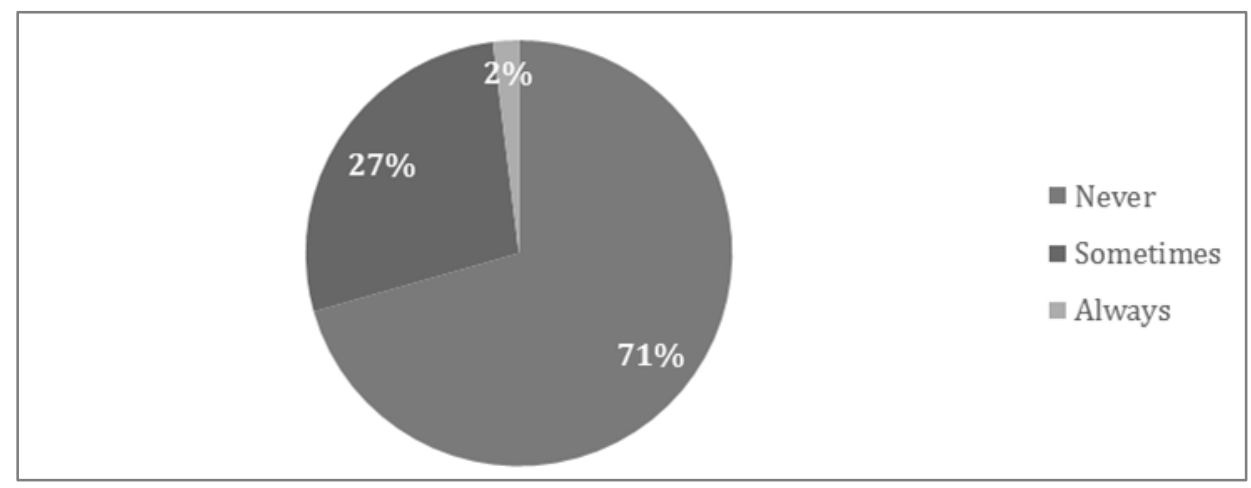

FIG. 8: Current use of BIM in Egyptian construction projects

\subsubsection{BIM Potential Benefits and Challenges}

In addition to the closed ended questions, the survey presented open ended question in which the experts could discuss their views on implementing BIM in fast-track projects in the Egyptian private sector. Some respondents indicated that "Visualization" would be one of the major aspects offered by BIM. They suggested that having a visual representation of a project during its early stages would be of great significance as it will give clients a better understanding of what to expect at project delivery; thus reducing CRR associated with change of scope or material based on lack of understanding. Such representation transforms implicit information into explicit information through the creation of three-dimensional model. This indicates that the process of accessing explicit information by clients and even contractors will help in delivering knowledge more appropriately and assures that the information will not be lost since everything is saved inside the model's database. Adding to this, they also identified that automatic quantity takeoff generated from the building model would provide reliable and accurate "Cost estimates." This implies that clients will have both better visualization and cost feedback at early stages of the project, which will help in better decision-making by clients that will eventually lead to less rework. This goes along with the theory stating that decisions made during early project phases, will have the greatest impact on the project performance regarding cost and schedule (Eastman et al., 2011).

On a different note, respondents stated that "Clash detection" would be another important feature of BIM. It would identify design discrepancies early on which they stated is highly frequent in drawings and documents produced by Egyptian designer, thus reducing possible design conflicts. Furthermore, "Clash detection" enables correction of design errors at an early stage prior to such work being initially executed, and thus requiring rework. This also aligns the literature by Azhar (2011) and Eastman et al. (2011) on the importance of BIM in detecting clashes. 
VALIDATION

\subsection{Overview}

In order to validate the benefits reaped through the use of BIM in the reduction of rework, projects that have utilized BIM from the literature have been investigated and compared with a case study in the Egyptian market. Nine projects in total have been investigated with metrics collected about the reduction in; the number of RFIs, cost of rework and schedule delays.

\subsection{This Study Project 1}

In order to further validate the hypothesis that the use of BIM can reduce CRR fast-track projects in the Egyptian construction private sector, a construction project that has implemented BIM was studied.

Project A is located in Sixth of October City in the governorate of Giza and is a commercial fast track project that employed BIM during the design stage. The project is composed of a shopping center, family entertainment and leisure complex that includes cinemas, an arcade game center and a children's play-acting center. The project's strategic objective is to aim to be Cairo's retail hub.

TABLE 8 presents the description of the project. As evident the project had an original contract price of 2.4 billion EGP, which is equivalent to 343 million USD in 2013 exchange rate (CBE, 2017).

\section{TABLE 8 Project A description}

\begin{tabular}{|l|l|}
\hline Type & Commercial Project \\
\hline Land Size & $282,000 \mathrm{~m} 2$ \\
\hline Built Up Area & $230,000 \mathrm{~m} 2$ \\
\hline Original Contract Price & 2.4 billion EGP \\
\hline Contract Type & Lump Sum \\
\hline Planned Project Duration & 3 years \\
\hline Year of Commencement & 2013 \\
\hline
\end{tabular}

Based on five interviews conducted with project team members including the Client, PM and Contractor, it was noted that initially a BIM model was created for the roof structure only. The roof was designed to house the majority of the electromechanical equipment, including chillers and cooling towers (FIG. 9). This equipment are heavy and require a Tower crane in order to place them on the roof. Nonetheless, such activities needed to be coordinated with the dynamic site layout and the lifecycle of the tower crane, to ensure that a tower crane was available in the required location at the time in which these activities took place. This was especially complicated by the fast-track nature of the project which resulted in a highly dynamic site layout. The use of BIM in this example minimizes the potential for rework since it ensures the logistics and coordination of construction activities. Moreover, utilization of BIM was extended to model the garage level, electrical substations and all electrical rooms, energy usage, and an indoor Ski system.

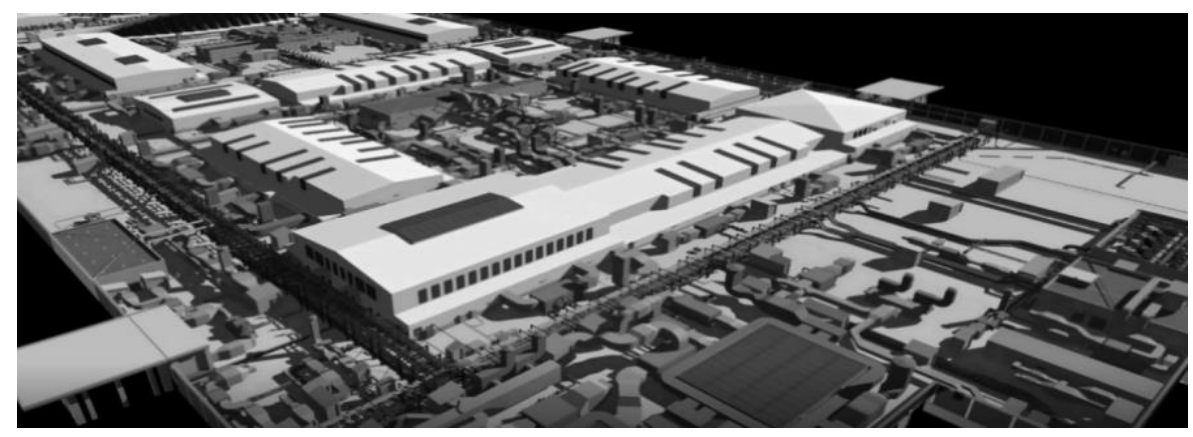

FIG. 9: BIM of project's roof structure 
Initially the garage level was not part of the BIM model, and this lead to significant rework being conducted. After the HVAC ductwork was executed in the garage level, the Client found the executed work aesthetically displeasing. Accordingly, the PM requested that the HVAC system be redesigned within a BIM environment. This enabled the Client to visualize how the system would look like prior to execution and make a decision accordingly. This provides an example of how BIM can help reduce CRR by helping Clients in their decision making process through the visualization of the works prior to execution.

Another example of how BIM was used to reduce rework was noted in the garage level. In this case a $4 \mathrm{~km}$ steel rack was executed in the garage level. Fabrication and erection of this structure was complicated by the turns that the structure took, leading to irregular sections at various locations. BIM was used to divide this structure into modules, where each module was then fabricated and preassembled in a controlled environment offsite, thus ensuring that quality is maintained, and reducing rework related to poor workmanship that exists in uncontrolled site conditions. Moreover, once these modules arrived onsite each numbered according to the numbering established in the BIM model, they were placed in their designated locations.

In order to assess how CRR affected the project in terms of cost and time, the project documents including; inspection requests and change orders, were analyzed. Each of the change orders in the project were separated by cause in order to establish which were instigated by the Client. Furthermore, the inspection requests submitted by the Contractor along with the Engineer's response were also evaluated in order to establish cases in which rework was undertaken and causes of such rework. Since the contract is a lump-sum contract, any CRR would be documented by the Contractor to ensure their ability to claim the added cost and time of such works. Based on this analysis it was found that CRR is responsible for approximately 280 million EGP, which translates to 11.7 percent increase in the price of the project. This percentage is significantly less than that presented by respondents who stated that CRR resulted in 22 percent increase in project cost. Moreover, CRR was only responsible for 10 percent delay in the project duration, based on the time claimed by the Contractor for CRR, which is also significantly less than the 23 percent increase in time reported by respondents.

Accordingly, Project A underlines how BIM have the ability to reduce CRR in Egyptian private sector projects, and the associated additional cost and delays that are incurred due to such rework.

\subsection{Neelamkavil and Ahamad (2012)-Project 2 and Project 3}

Project 2: Neelamkavil and Ahamed (2012) investigated the benefits in reduction of rework on the Denver Health Sciences Centre project, which was completed in June 2008 as part of the facility program plan adapted by the University of Colorado, valued at a total worth of \$201 million. Following being awarded to Continuum Partners, the application of a BIM driven approach for the project's construction, results recorded positive results in reduction of RFIs, change orders and notable schedule gains. The project analysis recorded a significant $74 \%$ reduction in construction RFIs during its foundation phase followed by a $47 \%$ during the steel erection phase. Overall and in comparison to a similar project, BIM adoption resulted in a $37 \%$ reduction RFIs and $32 \%$ reduction of change orders. The subject project's completion schedule, another gain caused by BIM utilization, recorded a two months ahead of schedule delivery. In contrast to a comparable study, the subject project stood at six months ahead of schedule. Due to BIM implementation, the project's team estimated a $50 \%$ reduction in both labor and work schedule

Project 3: Neelamkavil and Ahamed (2012) studied the use of BIM modeling in the design of a 4,180 m2 explosives pressing facility valued at $\$ 100$ million. The utilization of a virtual walk through BIM has helped in detecting clashes that could have caused over 500 problems. A total saving of 10\% ( $\$ 10$ million), generated by BIM modeling techniques through design stage, was one of the major benefits of utilizing BIM at early stage of the project.

\section{$5.4 \quad$ Fen et al. (2014)-Project 4 and Project 5}

Project 4: Fan et al. 2014 (2014) utilized data from Contractor 2 is trying to be pioneers in utilizing BIM in portfolio management and property development. The company employs in-house BIM experts, both architects and engineers, responsible for remodeling projects (smallest project worth \$2 million) and construction projects (largest project worth $\$ 200$ million). As an organizational strategy, the contractor keeps track records of all the data/results obtained from the executed BIM projects. Company 2 stated that there are great benefits that were generated through utilizing BIM in both the design and construction process. The benefits generated for Contractor 
2 are as follows: an approximate reduction of $90 \%$ on RFIs and the projects achieves shorter project duration with a significant decrease in the amount of rework/change orders

Project 5: Fan et al. (2014) also investigated projects from one of the US's top 20 commercial construction companies specializing in the hospital sector. The Contractor employs one BIM corporate manager, 2 BIM Project manager and 2 BIM operators in order to manage their BIM dynamics. The Contractor also currently generates a full BIM model for most of the healthcare facility construction project. However, BIM modeling is generally used to a certain extent in commercial projects. The results from BIM management strategy utilized by the Contractor in condensed schedule projects highlighted the effectiveness of BIM and encouraged them towards implementing BIM on most of their projects. The benefits realized by the Contractor are as follows: a reduction of $90 \%$ on RFIs, a recent BIM fully modeled $8,400 \mathrm{~m} 2$ hospital project experienced only 15 RFIs, where a typical 2D project from the same scale expects to have hundreds of RFIs. Also, BIM helped in reducing rework through early clash detection by $60 \%$. Moreover, the project was finalized 2 months earlier making a saving of $16 \%$ in schedule.

\subsection{Ham et al. (2018)-Project 6}

Project 6: Ham et al. (2018) analyzed the Haeundae L. project located in Busan South Korea. The project is composed of:

- Land area 35,751 m2, Built up Area of 661,134 m2.

- Total construction cost is 1.4 trillion won

- Landmark tower consisting of a hotel and an observatory with 5 underground floors and 101 floors above ground

- Towers A and B, composed of apartments and services with 5 basement floors and 85 above ground floor.

- Podium, with has 1 basement floor and 7 above ground floors, that house services and commercial area.

The project is being executed in a fast-tracked environment, and it was agreed between all parties that in order to reduce the risks associated with incomplete designs that BIM would be utilized in order to reduce potential risks. Through the use of BIM cost of rework was found to be reduced by 63.48 percent on the project compared to industry averages, with project delays also reduced by 38.41 percent.

\subsection{Giel et al. (2010)-Project 7 and 8}

Project 7: Giel et al. (2010) studied similar projects that employed BIM versus those that did not in condensed scheduled projects. The two BIM assisted projects were a commercial warehouse and a mixed use project. The commercial warehouse project is composed of $8,100 \mathrm{~m} 2$ utilizing a Guaranteed Maximum Price contract with one year duration. It was found that the project experienced 28 percent reduction in rework cost through the use of BIM compared to the construction of warehouses that have not utilized BIM, with a 100 percent reduction in delays.

Project 8: The mixed use project is composed of a 45,000 $\mathrm{m} 2$ seven story structure also utilizing a Guaranteed Maximum Price contract, with an original schedule of 652 days. When comparing the findings from the project compared to similar mixed use projects that have not utilized BIM, it was found that the cost of rework was reduced by 90 percent with schedule delays also reduced by 100 percent.

\subsection{Barlish (2011)-Project 9}

Project 9: Barlish (2011) compared projects that utilized BIM versus those that did not. The study compared two non BIM projects with two similar BIM projects and found that the cost of rework was reduced by 42 percent, with the delay in schedule reduced by 67 percent. Moreover, the number of RFIs were also reduced by 50 percent.

\section{$5.8 \quad$ Summary}

As can be in Table 9 the use of BIM in fast-tracked projects can have a positive effect on the reduction of rework in the construction industry. Such reduction of rework can reduce both the added costs associated with rework as well as potential delays. Comparing the case study from the Egyptian construction industry with previously conducted statistical studies it evident that the Egyptian construction industry is consistent with other markets as well. The case studies from other case studies in literature presented an average reduction in rework of 47 percent which is similar to that in the Egyptian case study of 49 percent reduction in the cost of rework. Moreover, while 
the case studies from previous studies presented a reduction in schedule delays of 62 percent, the Egyptian market also presented similar reductions of 57 percent.

Table 9. Summary of Case Studies' findings

\begin{tabular}{|c|c|c|c|c|c|c|c|c|c|}
\hline \multirow[t]{3}{*}{$\%$ Reduction } & \multicolumn{9}{|c|}{ Case Studies } \\
\hline & \multirow{2}{*}{\begin{tabular}{|c|} 
This Study \\
P1 \\
\end{tabular}} & \multicolumn{2}{|c|}{$\begin{array}{l}\text { Neelamkavil and } \\
\text { Ahmed (2012) }\end{array}$} & \multicolumn{2}{|c|}{ Fen et al. (2014) } & \multirow{2}{*}{$\begin{array}{c}\begin{array}{c}\text { Ham et al. } \\
(2018)\end{array} \\
\text { P6 }\end{array}$} & \multicolumn{2}{|c|}{ Giel et al. (2010) } & \multirow{2}{*}{\begin{tabular}{|c} 
Barlish (2011) \\
P9
\end{tabular}} \\
\hline & & $\mathrm{P} 2$ & P3 & $\mathrm{P} 4$ & P5 & & P7 & P8 & \\
\hline RFIs & 40 & 37 & - & - & 90 & - & - & - & 50 \\
\hline Rework & 49 & 32 & 10 & - & 60 & 63 & 28 & 90 & 42 \\
\hline Schedule & 57 & 50 & - & - & 16 & 38 & 100 & 100 & 67 \\
\hline
\end{tabular}

\section{CONCLUSIONS AND RECOMMENDATIONS}

\subsection{Conclusion}

This study investigated the status of Client Related Rework in fast-track construction projects in the Egyptian private sector, analyzed the causes of CRR, explored the perceived impact of the causes regarding projects cost, schedule and quality performance, examined the potential benefits BIM would offer in enhancing the reduction of CRR, and the challenges that BIM would face to be utilized by the private sector in the Egyptian market. The outcomes of the questionnaire survey highlighted that the client was the major contributor in causing rework in fast-track projects. Also, the analysis of the results reported that 64.7 percent of the construction professionals that were surveyed in this study encountered CRR on more than 50 percent of projects, implying that CRR was still a common problem in the fast-track construction projects in the Egyptian private sector. Additionally, CRR increased project cost by 22 percent and led to a 23 percent schedule delay based on a 156-week average project duration.

By identifying the main contributors to CRR and the sources that provide the highest severity, project participants can begin to focus on reducing the frequency of causes that appear in high frequency such as "impediment in promoting decision making process", as well as reducing the impact of causes such as "replacement of materials by the client" which highly affect the project in terms of cost and time. Accordingly, the findings conducted through the survey can help participants in their risk planning and monitoring stages.

Regarding the causes of CRR, the analysis of the results indicated that the Egyptian market experiences a high frequency of client's changing the scope of the project, facing financial problems and engaging in slow decisionmaking processes. Moreover, it was found that "Replacement of materials by the client," "Change of scope by the client" and "Clients lacking a clear project objective" contributed most to CRR. Moreover, six out of the seven causes had a significant impact on cost, schedule, and quality performance of the project. Both CRs and Contactors agreed on the ranking of causes regarding the impact on quality performance but held different views on the rankings of the impact on cost and schedule performance. Additionally, using a novel Weighted Severity Index, it was identified that "Replacement of materials by the client" was perceived as the most severe of the CRR causes and thus project parties need to focus their attention on this causes in order to improve overall project performance.

As a potential remedy for CRR, BIM was introduced as a possible solution. The results of the survey showed that the majority of the respondents were familiar with BIM, however the respondents indicated that computer visualization techniques have yet to be embraced by the industry. Also, the analysis of results signified that the application of BIM in fast-track projects has the potential to provide better visualization, reliable cost estimates and detecting clashes at early project stages. All these advantages together will enable better communication between parties and enhance the availability of information; generate different scenario, and provide more accurate cost estimates of such scenarios. This will provide the client with a clearer understanding of the project, and aid in the client's decision-making process hence reducing rework at an early project stage.

It is evident that the Egyptian construction industry exhibits similar trends to the international market, which highlights ability to utilize learning outcomes found in other studies in a bid to reduce CRR in the Egyptian construction industry 
As clients reflect on the current economic situation facing the construction industry, in Egypt and elsewhere, there will be growing pressure and need to make changes to ensure cost and time is minimized. Furthermore, within countries whose lending interest rate is high, clients will potentially be inclined to adopt fast-track procurement in order to reduce financing cost. However, if a fast-track approach is undertaken without the necessary planning, CRR will potentially take place thus increasing the project duration, and consequently financing cost. Through the adoption and use of BIM, CRR can be significantly reduced thus presenting a solution that is expected to increase in popularity in its use in fast-track projects. Such an increase in clients demanding BIM will ensure that industry participants are forced to undertake the transition, and will deem such a transition economically feasible.

\subsection{Limiations}

Despite the achievement of the objectives, this study has some limitations. Firstly, although this study identified seven causes of CRR, they may not be comprehensive, accordingly additional research should be conducted to identify potential additional causes of CRR in the Egyptian construction industry. Secondly, the sampling frame in this study may not be inclusive of all the professionals participating in fast-track projects in the Egyptian private sector. Also, the findings from this study were well interpreted in the context of the Egyptian private sector, which may be different from the context of the public sector and even other countries. Thirdly, the impact of CRR on the quality performance requires more in-depth research. Lastly, the expected benefits that BIM would add, limitations to BIM application and the frequency, contribution, and impact of causes of CRR were assessed based on the experience perception and experience of the respondents. Thus, the data inevitably involved subjectivity.

\subsection{Recommendations}

The first step towards achieving better project performance is through creating awareness regarding the potential benefits of BIM in enhancing the reduction of rework. In this sense, clients would acknowledge that they can deliver ultimate worth to their organizations if they examined and improved BIM strategies, constructed a rigid internal leadership strategy and acquired knowledge. The clarity about BIM being a possible solution to CRR would encourage clients to utilize BIM and hence start including BIM-specific prequalification criteria in some of their Requests for Proposals (RFPs) for prospective bidders. This would be a good indication of the clients' willingness to start hiring service providers who are BIM project experts, teaching, and enlightening service providers, which in term will lead to motivating contractors and architects to invest in acquiring BIM techniques.

\subsection{Future Research}

The literature and findings of this study focused heavily on the impact of CRR with regards to cost and schedule performance, with limited importance given to the impact on quality performance. Therefore, it would be interesting to conduct further research on the impact of CRR on the quality performance of projects. Regarding BIM, future studies are recommended to investigate the ways to encourage clients to start moving away from traditional delivery methods, more specifically to support BIM application. Moreover, it should be noted that studying the causes of rework can be complicated given that constant changes of scope mean that finding a control reference point can be difficult. Accordingly, future research needs to be conducted to primarily focus on the effect of change of scope on rework.

\section{REFERENCES}

Acret, J. (2016). Drafting Construction Contracts. California Construction Contracts, Defects and Litigation.

Arain, F. M., \& Pheng, L. S. (2006). Developers' views of potential causes of variation orders for institutional buildings in Singapore. Architectural Science Review, 49(1), 59-74.

Azhar, S. (2011). Building information modeling (BIM): Trends, benefits, risks, and challenges for the AEC industry. Leadership and Management in Engineering, 11(3), 241-252.

Barlish, K (2011). How to Measure the Benefits of BIM. Master of Science Thesis, Arizona State University.

British Standards Institute (BSI) (2017). What is BIM? Building Information Modeling. BS 1192:2007+A2:2016.

Burati, J.; Farrington, J.; Ledbetter, W. (1992). Causes of Quality Deviations in Design and Construction. Journal of Construction Engineering and Management, 118(1), 34-49. 
CAPMAS (2019). Annual Report. Central Agency for Public Mobilization and Statistics.

CAPMAS (2017). Egyptian National Census. Central Agency for Public Mobilization and Statistics

CBE (2018). Annual Report 2016/2017. 2018. http://www.cbe.gov.eg (accessed on 20 August 2019). Central Bank of Egypt

CBE (2017). Annual Report 2015/2016. 2017. http://www.cbe.gov.eg (accessed on 20 August 2019). Central Bank of Egypt

CBE (2016). Annual Report 2014/2015. 2016. http://www.cbe.gov.eg (accessed on 20 August 2019). Central Bank of Egypt

Construction Industry Institute (CII). (2005). Making zero rework A reality. RS 203-1 (Nov.). The Univ. of Texas at Austin, Austin, Tex.

CMAA. (2007). An Owner's Guide to Construction Management: Assuring Project Success Under Any Delivery Method. Construction Management Association of America.

CRC Construction Innovation. (2007). Adopting BIM for Facilities Management: Solutions for Managing the Sydney Opera House. Cooperative Research Center for Construction Innovation, Brisbane, Australia.

Dörnyei, Z. (2003). Questionnaires in second language research construction, administration and processing. Research methods in applied linguistics. Oxford: Oxford University Press.

Eastman, C., Teicholz, P., Sacks, R., \& Liston, K. (2011). BIM handbook : a guide to building information modeling for owners, managers, designers, engineers, and contractors (2nd ed.). Hoboken, NJ: Wiley.

Elvin, G. (2007). Integrated Practice in Architecture: Mastering Design-Build, Fast-Track, and Building Information Modeling. ISBN: 978-0-471-99849-5.

Fan, S.L.; Skibniewski, M.J.; Hung, W.T (2014). Effects of Building Information Modeling During Construction. Journal of Applied Science and Engineering, 17(2),.157-166

Giel, B.; Issa, R.R.A.; Olbina, S (2010). Return on Investment analysis of Building Information Modeling in Construction, International Conference on Computing in Civil and Building Engineering.

Ham, N.; Moon, S.; Kim, J.H.; Kim, J.J (2018). Economic Analysis of Design Errors in BIM-Based High-Rise Construction Projects: Case Study of Haeundae L Project. Journal of Construction Engineering and Management; 144(6), Article no. 05018006.

Hwang, B. G., Zhao, X., \& Goh, K. J. (2014). Investigating the client-related rework in building projects: The case of Singapore. International Journal of Project Management, 32(4), 698-708.

Hwang, B., Thomas, S., Haas, C., \& Caldas, C. (2009). Measuring the Impact of Rework on Construction Cost Performance. Journal of Construction Engineering and Management, 135(3), 187-198.

Khoueiry, Y., Srour, I., \& Yassine, A. (2012). An Optimization Model for Maximizing the Benefits of Fast-tracking Construction Projects. Construction Research Congress 2012: Construction Challenges in a Flat World, 247-257.

Lee, G., Park, H.K., \& Won, J. (2012). D3 City project — Economic impact of BIM-assisted design validation. Automation in Construction, 22, 577-586.

Love, P. E., \& Edwards, D. J. (2004). Determinants of rework in building construction projects. Engineering, Construction and Architectural Management. 11(4), 259 - 274.

Love, P., Davis, P., Ellis, J., \& On Cheung, S. (2010). Dispute causation: identification of pathogenic influences in construction. Engineering, Construction and Architectural Management, 17(4), 404-423.

Marshall, G (2005). The purpose, design and administration of a questionnaire for data collection. Radiography, 11(2), 131136.

Marzouk, M.M. \& El-Rasas, T.I. (2014). Analyzing delay causes in Egyptian construction projects. Journal of Advanced Research , 5(1), 49-55.

McDuffie, H. T. (2006). BIM: transforming a traditional practice model into technology-enabled integrated practice model. The Cornerstone, AIA. 
National Institute of Building Science (2018). National Building Information Modeling Standard: Overview, principples and methdologies. https://www.nationalbimstandard.org/faqs (accessed 10 May 2018)

Ndihokubwayo, R. \& Haupt, T.C. (2008). Uncovering the origins of variation orders. Proceedings of the 5th Post Graduate Conference on Construction Industry Development, Bloemfontein, South Africa, 16-18 March 2008.

Neelamkavil, J.; Ahamed, S. S (2012). The Return on Investment from BIM-driven Projects in Construction. Research Report (National Research Council of Canada. Institute for Research in Construction)

Palaneeswaran, E. (2006). Reducing rework to enhance project performance levels. Proceedings of the one day seminar on recent developments in project management in Hong Kong.

Pena-Mora, F., \& Park, M. (2001). Dynamic planning for fast-tracking building construction projects. Journal of construction engineering and management, 127(6), 445-456.

Roscoe, J.T. (1975) Fundamental Research Statistics for the Behavioural Sciences, 2nd edition. New York: Holt Rinehart \& Winston.

Smith, D. K., \& Tardif, M. (2009). Building information modeling : a strategic implementation guide for architects, engineers, constructors, and real estate asset managers. Hoboken, N.J.: Wiley.

Swefie, M.G. (2013). Improving project performance using lean construction in Egypt: A proposed framework. American University in Cairo Thesis.

Teicholz, P. (2013). BIM for facility managers . Hoboken, N.J.: Wiley .

Thomson, D.S., Austin, S.A., Devine-Wright, H. and Mills, G.R. (2003). Managing value and quality in design. Building Research \& Information Journal, 31(5), 334-345.

Zhang, Y. and Wang, G. (2009). Cooperation between Building Information Modeling and Integrated Project Delivery Method Leads to Paradigm Shift of AEC Industry. International Conference on Management and Service Science 